\title{
ANALISIS MODEL PEMBELAJARAN BERKARAKTER DAN RELEVANSINYA TERHADAP PENDIDIKAN ISLAM (Studi Analisis Manajemen Pendidikan Karakter Perspektif E. Mulyasa)
}

\section{Redha Dwi Rizkia}

Fakultas Agama Islam Universitas Wiralodra

E-Mail: redhadwirizkiao4@gmail.com

\section{Zaedi}

Fakultas Agama Islam Universitas Wiralodra

E-Mail: zaidim62o@gmail.com

\begin{tabular}{|c|c|c|}
\hline Received & Revised & Accepted \\
\hline 4 July 2019 & 2 Agustus 2019 & 20 Agustus 2019 \\
\hline
\end{tabular}

\section{AN ANALYSIS OF CHARACTER LEARNING MODEL AND IT'S RELEVANCE TO ISLAMIC EDUCATION}

(An Analysis Study of Character Education Management in E. Mulyasa Perspective)

\begin{abstract}
This study aims to describe the analysis of character learning models and its relevance to Islamic education based onstudy Prof. Dr. Mulyasa . The method used in this study is a qualitative method with the type of library research. The results show that the character learning model is a learning model using habituation and exemplary methods, disciplinary guidance, rewards and punishments, contextual teaching and learning, role playing, and participatory learning. Some of the learning models are expected to create an atmosphere that is effective and efficient and can shape the character of good students. The relevance of the character learning model according to E.Mulyasa with Islamic education is to have the same linkages or goals, both of which want to shape the noble character which is the real goal of education.
\end{abstract}

Keywords: learning models, character education, and islamic education 


\begin{abstract}
Abstrak
Penelitian ini bertujuan untuk mendeskripsikan analisis model pembelajaran berkarakter dan relevansinya terhadap pendidikan islam berdasarkan studi pemikiran Prof. Dr. Mulyasa. Metode yang digunakan penelitian ini adalah metode kualitatif dengan jenis penelitian studi pustaka (library research). Hasilnya menunjukan bahwa model pembelajaran berkarakter adalah model belajar dengan menggunakan metode pembiasaan dan keteladanan, pembinaan disiplin, hadiah dan hukuman, CTL (contectual teaching and learning), bermain peran (role playing), dan pembelajaran partisipatif (Participative intruction). Dari beberapa model pembelajaran tersebut diharapkan dapat menciptakan suasana yang efektif dan efisien dan dapat membentuk karakter siswa yang baik. Adapun relevansi tentang model pembelajaran berkarakter menurut E.Mulyasa dengan pendidikan Islam yaitu memiliki keterkaitan atau tujuan yang sama, yaitu keduanya sama-sama ingin membentuk karakter/akhlak yang berakhlakul kharimah yang mana itu merupakan tujuan sebenarnya dari pendidikan.
\end{abstract}

Kata kunci: model pembelajaran, pendidikan karakter, dan pendidikan islam

\title{
Pendahuluan
}

Berbicara mengenai pendidikan tentu tak lepas dari adanya pembelajaran, pembelajaran merupakan aktualisasi kurikulum yang menuntut keaktifan guru dalam menciptakan dan menumbuhkan kegiatan peserta didik sesuai dengan rencana yang telah diprogramkan ${ }^{1}$. Proses belajar mengajar mempunyai makna dan pengertian yang lebih luas daripada pengertian mengajar. Dalam proses belajar-mengajar tersirat adanya satu kesatuan kegiatan yang tidak bisa terpisahkan antara siswa yang belajar dan guru yang mengajar ${ }^{2}$.

Belajar pada hakikatnya adalah proses interaksi terhadap semua situasi yang ada di sekitar individu. Belajar dapat dipandang sebagai proses yang diarahkan kepada tujuan dan proses perbuatan melalui berbagai pengalaman belajar juga merupakan proses melihat, mengamati, dan memahami sesuatu kegiatan, pembelajaran dilakukan oleh dua orang pelaku, yaitu guru dan siswa ${ }^{3}$. Secara konseptual belajar merupakan suatu proses perubahan yaitu perubahan tingkah laku sebagai hasil dari interaksi dengan lingkungannya dalam memenuhi kebutuhan hidupnya ${ }^{4}$.

Di zaman globalisasi ini menuntut setiap bangsa memiliki sumber daya manusia yang berdaya tahan kuat dan perilaku yang handal. Sumber daya yang berkualitas hanya dapat diperoleh melalui pendidikan yang berkualitas unggul. Dari sistem pendidikan yang unggul inilah muncul generasi bangsa yang unggul. Munculnya globalisasi juga telah menambah masalah baru bagi dunia

\footnotetext{
${ }^{1}$ H E Mulyasa, “Manajemen Pendidikan Karakter, Cet," V, Jakarta: Bumi Akara, 2013, 165.

2 Moh Uzer Usman, "Menjadi Guru Profesional," Bandung: PT. Remaja Rosdakarya, 2002.

${ }^{3}$ Dr Rusman and M Pd, “Model-Model Pembelajaran," Raja Grafindo, Jakarta, 2012.

${ }^{4}$ M Mulyono and Ismail Suardi Wekke, "Strategi Pembelajaran Di Abad Digital" (Yogyakarta: Penerbit Gawe Buku, 2018).
} 
pendidikan ${ }^{5}$. Globalisasi komunikasi informasi yang seolah tak terbendung mengantar pada globalisasi budaya yang tengah memasuki masyarakat Indonesia. diantara permasalahan yang ada diantaranya konflik SARA, korupsi, kenakalan remaja, tauran antar pelajar, penyalahgunaan narkoba, seks bebas, maraknya angka kekerasan dari pelecehan seksual terhadap anak-anak dan remaja, pencurian remaja, kebiasaan menonton pornografi adalah bagian persoalan yang mendera mayarakat Indonesia.

Tantangan yang sangat serius terkait dampak dari globalisasi, diantara tantangan yang paling fundamental adalah masalah karakter anak didik. Sebuah keresahan yang cukup beralasan bagi orang tua jika melihat perkembangan pergaulan saat ini. Dominasi hiburan yang kerap menyeret anak-anak dalam keterlenaan $^{6}$. Sehingga mengikuti perilaku-perilaku negative seperti tidak hormat kepada guru, berkata kasar dan tidak punya sopan santun, sering tawuran, memiliki geng disekolah, melakukan prilaku bullying kepada teman bahkan sampai kepada gurunya sendiri. Krisis yang melanda masyarakat Indonesia mulai dari pelajar dan elite politik, mengindikasikan bahwa pendidikan Agama dan moral yang diajarkan dibangku sekolah, tidak berdampak pada perubahan perilaku masyarakat Indonesia. Permasalahan-permasalahan ini tentu menjadi pertanyaan kita semua mengapa hal ini bisa terjadi ada apa dengan banga yang dikenal dengan adat ketimuran ini apakah ada yang salah dalam mendidik dan memberikan pengajaran kepada generasi bangsa ini hingga melahirkan berbagai persoalan tesebut.

Permasalahan pendidikan sebenarnya sangat banyak. Selama ini permasalahan pendidikan hanya diketahui permukaanya saja. ${ }^{7}$ Bangsa kita menaruh harapan baru terhadap dunia pendidikan. dari pendidikan inilah diharapkan masa depan bangsa Indonesia dibangun dalam landasan yang kuat. Landasan yang berpijak pada norma-norma Agama. Landasan yang mampu mendirikan anak banga dengan berbagai potensi yang dimiliknya ${ }^{8}$. Pendidikan merupakan sarana efektif untuk menanamkan nilai dan sikap antikorupsi sejak dini di kalangan peserta didik ${ }^{9}$.

Diyakini bahwa kotak hitam (black box) pendidikan adalah di ruang kelas, lebih khusus pada proses pembelajaran. Tidak sedikit peserta didik telah menjadi korban salah ajar (malteaching), dan selama ini pikiran peserta didik

\footnotetext{
${ }^{5}$ Implementasi Pendidikan, Karakter Dalam, and Ali Miftakhu Rosyad, “Al-Afkar, Journal for Islamic Studies Ali Miftakhu Rosyad IMPLEMENTASI PENDIDIKAN KARAKTER DALAM PEMBELAJARAN PENDIDIKAN AGAMA ISLAM DI SEKOLAH MUHAMMADIYAH DI KABUPATEN INDRAMAYU Al-Afkar, Journal for Islamic Studies THE IMPLEMENTATION OF CHARACTER EDUCATION THROUGH LEARNING OF ISLAMIC STUDIES IN MUHAMMADIYAH SCHOOL IN INDRAMAYU DISTRICT" 4, no. 1 (2019), https://doi.org/10.5281/zenodo.3321357.

${ }^{6}$ Winarno Herimanto, “Ilmu Sosial Dan Budaya Dasar,” Jakarta: Bumi Aksara, 2008.

${ }^{7}$ Zaenudin, Ibnu Rusydi, Kurnaengsih, Filsafat Pendidikan Islam, (Yogyakarta: K-Media 2017) 13

${ }^{8}$ Najib Sulhan, “Pendidikan Berbasis Karakter," Surabaya: PT JePe Press Media Utama, 2010.

${ }^{9}$ Abd. Rachman Assegaf, Filsafat Pendidikan Islam: Paradigma Baru Pendidikan Hadhari Berbasis IntegratifInterkonektif (PT RajaGrafindo Persada, 2011).
} 
tidak tersekolahkan (unschool mind) akibat dari pembelajaran yang kurang efektif tersebut ${ }^{10}$.

Oleh karena itu guru merupakan faktor penting yang besar pengaruhnya terhadap keberhasilan pendidikan disekolah, bahkan sangat menentukan berhasil tidaknya peserta didik dalam mengembangkan pribadinya secara utuh. Berbagai kasus ditemukan bahwa diantara para guru banyak yang merasa dirinya sudah dapat melakukan pembelajaran dengan baik, meskipun tidak dapat menunjukkan alasan yang mendasari asumsi tersebut ${ }^{11}$.

Tugas guru yang paling utama dalam pendidikan karakter disekolah adalah bagaimana mengkondisikan lingkungan belajar yang berkarakter, menyenangkan agar dapat membangkitkan rasa ingin tahu semua peserta didik sehingga tumbuh minat dan karakter baiknya. Dalam hal ini guru-guru hendaknya memposisikan diri sebagai fasilitator, yang tugas utamanya memberikan kemudahan belajar kepada peserta didik (to facilitate learning), tanpa ada pemaksaan dan kekerasan terhadap peserta didik, sebab pemaksaan dan kekerasan hanya akan membekaskan sesuatu yang kurang positif dikalangan pribadi peserta didik, yang nantinya akan membentuk karakter mereka ${ }^{12}$. Karna guru sebagai pengganti orang tua disekolah perlu memiliki kesadaran, pemahaman, kepedulian, dan komitmen untuk membimbing peserta didik menjadi manusia-manusia sholeh yang bertaqwa. Di dalam lingkup pendidikanpun tidak sedikit guru yang memberikan contoh yang buruk kepada peserta didik, masih banyaknya guru yang tidak memahi kompetensi guru seperti, rendahnya pemahaman tentang pembelajaran, kurang mahir dalam mengelola kelas yang mengakibatkan kejenuhan bagi peserta didik, jarang mengajar, sering terlambat bahkan melakukan tindak asusila. Sehingga berdampak buruk bagi perkembangan peserta didik yang mana tindakan itu akan diikuti oleh peserta didik. Oleh karena itu seorang guru harus meberikan pembelajaran yang baik sehingga peserta didik menjadi manusia yang sholeh dan bertaqwa. Allah SWT telah berfirman dalam (QS. Al-Ahdzab ayat 21)

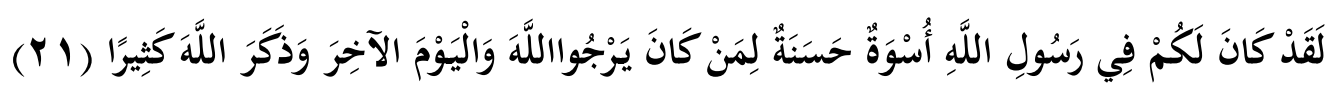

Sesungguhnya telah ada pada iri Rasulullah itu suri teladan yang baik bagimu (yaitu) bagi orang yang mengharap (rahmat Allah dan (kedatangan) hari kiamat dan ia banyak menyebut Allah. (Qs. Al Ahdzab:21 $)^{13}$

Dari ayat diatas sudah jelas jika seorang guru mendidik peserta didik dengan ikhlas serta mengikuti sifat dan sikap keteladanan Rasulullah SAW dengan baik maka dalam pembelajaran tentu banyak amal yang telah ditabung untuk kehidupan diakhirat kelak. Dalam upaya membentuk peserta didik menjadi shaleh tersebut maka diperlukannya guru yang mampu membimbing

\footnotetext{
${ }^{10}$ Mulyono and Wekke, "Strategi Pembelajaran Di Abad Digital."

${ }^{11}$ Mulyasa, "Manajemen Pendidikan Karakter, Cet."

12 Mulyasa.

${ }^{13}$ Departemen Agama RI, Al-Qur'an dan Terjemah Special For Woman, (Bandung; Sygma exagrafika, 2009), 420
} 
mereka dengan pendekatan berkarakter dimulai dari proses pembelajaran berkarakter dalam proses pembelajaran ini guru dapat menerapkan nilai-nilai kebaikan dalam tindakan nyata atau perilaku sehari-hari, dan dalam pembelajaran perlu disampaikan dalam suasana interaktif, menyenangkan, menggembirakan, penuh dorongan, motivasi, dan memberikan ruang gerak yang lebih leluasa kepada peserta didik dalam membentuk kompetensi dirinya untuk mencapai tujuan. Sesuai dengan cita-cita dan tujuan pendidikan nasional, guru perlu memiliki beberapa prinsip mengajar yang mengacu pada peningkatan kemampuan internal peserta didik di dalam merancang strategi dan melaksanakan pembelajaran. Oleh karena itu upaya untuk merancang strategi pembelajaran guru harus mengetahui model pembelajaran yang dapat diterapkan dikelas.

Berdasarkan latar belakang yang telah diuraikan diatas penulis memilih salah satu buku Prof. Dr. H. E. Mulyasa, M.Pd dengan judul analisis model pembelajaran berkarakter dan relevansinya terhadap pendidik Islam, karena beliau merupakan guru besar dan salah satu pakar dibidang pendidikan. Buku yang peneliti pilih sangat menarik untuk diteliti karena berkaitan dengan judul yang akan diteliti. Dan tema ini sengaja dipilih karena menarik perhatian untuk dicermati dan perlu dukungan dari semua pihak yang peduli terhadap dunia pendidikan khususnya Islam. Karena model pembelajaran ini sangat berpengaruh dalam proses pembelajaran dan sebagai guru Agama bisa menerapkan model pembelajaran yang baik terhadap peserta didik, jadi bukan hanya sekedar mengajar tapi juga mendidik dengan cara pembiasaan, keteladanan sehingga membentuk karakter yang berakhlakul karimah sesuai dengan tujuan pendidikan Islam.

Adapun dalam melakukan penelitian terdapat bebarapa kesulitan yang dialami oleh peneliti diantaranya dalam mencari judul sesuai dengan masalah yang ada, kemudian mencari sumber data yang berkaitan dengan tema yang diangkat, seperti mencari buku-buku penunjang, informasi lainnya, dan mencari ayat Al-Qur'an yang sesuai dengan tema, kemudian mencari hasil studi penelitian terdahulu dengan berkunjung keperpustakaan dan mengakses di internet seperti jurnal-jurnal atau karya ilmiah lainnya. Kemudian masalah yang sangat serius yang dihadapi peneliti ketika file data hilang dan harus mengetik ulang sehingga menghambat waktu untuk penyusunan ketahap selanjutnya.

Dalam penelitian ini tentunya penting bagi kita untuk mengetahui bagaimana proses pembelajaran berkarakter sehingga guru dapat memberikan pengajaran yang baik bagi peserta didik. Dengan demikian peneliti tertarik untuk mengadakan penelitian yang berjudul "Analisis Model Pembelajaran Berkarakter Dan Relevansinya Terhadap Pendidikan Islam (Studi Analisis Buku Manajemen Pendidikan Karakter Karya E. Mulyasa) 


\section{Metode Penelitian}

Dalam penelitian ini, peneliti menggunakan penelitian kualitatif. Penelitian kualitatif merupakan suatu penelitian yang ditujukkan untuk mendeskripsikan dan menganalisis fenomena, peristiwa, aktifitas social, sikap, kepercayaan, persepsi, pemikiran orang secara individual maupun kelompok. ${ }^{14}$ Penelitian skripsi ini termasuk kedalam jenis penelitian kepustakaan (Library Resaerch) artinya bahan-bahan atau data-data dalam penelitian diperoleh melalui penggalian dan penelitian sejumlah literatur berupa buku-buku, artikel, jurnal, surat kabar, web (internet) dan sumber lainnya yang dinilai mempunyai hubungan dan dapat mendukung pemecahan masalah ${ }^{15}$. Secara rasional yang terarah dan mendalam dengan cara mencari data yang berkaitan dengan kajian model pembelajaran berkarakter dan relevansinya terhadap pendidikan Islam.

Teknik Pengumpulan Data

Teknik pengumpulan data merupakan langkah yang paling strategis dalam penelitian, karena tujuan utama dari penelitian adalah mendapatkan data ${ }^{16}$. Dalam penelitian kualitatif, teknik pengumpulan data yang utama adalah observasi, wawancara mendalam studi dokumentasi, dan gabungan ketiganya atau triangulasi ${ }^{17}$. Dalam penelitian ini peneliti menggunakan teknik Observasi dan dokumentasi, berikut penjelasannya:

a. Teknik Observasi

Teknik observasi merupakan pengamatan atau aktivitas terhadap suatu proses atau objek dengan maksud merasakan dan kemudian memahami pengetahuan dari sebuah fenomena berdasarkan pengetahuan dan gagasan yang sudah diketahui sebelumnya, untuk mendapatkan informasi-informasi yang dibutuhkan untuk melanjutkan suatu penelitian. ${ }^{18}$

b. Teknik Dokumentasi

Teknik dokumentasi merupakan cara peneliti untuk mencari catatan peristiwa yang sudah berlalu. Dokumen biasa berbentuk tulisan, atau karyakarya monumental dari seseorang. Dokumen yang berupa tulisan misalnya catatan harian, sejarah kehidupan, ciretera, biografi, peraturan, kebijakan. Dokumen yang berbentuk gambar hidup, sketsa dan lain-lain. ${ }^{19}$

\footnotetext{
14 As'ad, Jenis-jenis Metode kualitatif, (http:/a2dcollection.blogspot.com/2017/03/Jenis-jenis-metodepenelitian-kualitatif.html) 2017, 30, Januari 2019

${ }^{15}$ Sugiyono, Metode Penelitian Pendidikan:(Pendekatan Kuantitatif, Kualitatif Dan R \& D) (Alfabeta, 2008).

${ }^{16}$ Sugiyono.

${ }^{17}$ Sugiyono.

18 Zakky, Zona Referensi,Https://www.zonareferensi.com/pengertian-observasi/ 2018

${ }^{19}$ Sugiono, Metode Penelitian Kuantitatif, Kualitatif Dan R\&D, (Bandung, Cv Alvabeta, 2009) 240
} 


\section{HASIL DAN PEMBAHASAN}

\section{Biografi Prof. Dr. H. E. Mulyasa, M.Pd}

Nama lengkap Enco Mulyasa, dilahirkan 13 Desember 1962 di Desa Ciranjang, Kecamatan Cingabul Kabupaten Majelengka Jawa Barat. Ayahnya Djuardi (alm) ibunya bernama Ibu $\mathrm{Hj}$. Rumtini. Dan ayahnya di masa hidupnya menekuni profesinya sebagai guru. E. Mulyasa merupakan putra penengah dari lima bersaudara ${ }^{20}$.

Kegiatan mengajarnya dimulai sejak tahun 1985, menjadi guru di beberapa sekolah menengah di Bandung. Ia juga menjadi asisten dosen pada jurusan Kurikulum dan Teknologi Pendidikan FIP IKIP Malang, Pada tahun 1988-2005, kemudian menjadi Dosen Kopertis Pascasarjana Universitas Islam Nusantara Bandung ${ }^{21}$.

Beliau Jabatannya sebagai Guru Besar Manajemen Pendidikan dan Pengembangan Kurikulum diraih pada tahun 2007. Dari tahun 2008 sampai sekarang kemudian diamanahi tugas untuk menjabat sebagai Ketua Program S2 Magister Manajemen Pendidikan di PPS UNINUS, serta menjadi ketua Lembaga Penjamin Mutu UNINUS, tahun 2008 juga menjadi Tim Penilai angka kredit bagi kenaikan jabatan dosen di lingkungan kopertis Jawa Barat dan Banten. ${ }^{22}$

Untuk menunjang profesinya, beliau aktif mengikuti berbagai kegiatan seminar dan pelatihan, baik bersifat lokal, regional, nasional maupun internasional. ${ }^{23}$ Prof Dr. H. E. Mulyasa, menempuh Pendidikan dasar dan menengah di daerah kelahirannya. Ia memperoleh gelar Sarjana Pendidikan (1986) dan Gelar Magister Pendidikan (1997) dari IKIP Bandung (sekarang UPI), tahun 2002 memperoleh gelar Doktor Ilmu Pendidikan $\left(\mathrm{S}_{3}\right)$ dari Universitas Pendidikan Indonesia, dengan predikat Cumlaude. ${ }^{24}$

Di sela - sela kesibukan sebagai dosen dan penulis, ia juga menjadi konsultan dan narasumber dalam berbagai forum sosialisasi kurikulum serta seminar pendidikan dan pengembangan sumber daaya manusia khususnya di Pulau Jawa, Bali, NTT, Kalimantan Selatan dan Sulawesi Selatan. ${ }^{25}$

Demikian riwayat hidup singkat dari. Dr. E. Mulyasa, M.Pd. yang dapat penulis gambarkan. Sampai saat ini beliau masih aktif khususnya dalam bidang pendidikan.

Karya-karya Ilmiah Prof. Dr. E. Mulyasa, M.Pd

Prof. Dr. E. Mulyasa, M.Pd. sebagaian besar memiliki bobot dan telah banyak menjadi rujukan atau referensi utama bagi para praktisi pendidikan, pengambil kebijakan pendidikan. Semuanya bertujuan untuk merespons tanggapan juga berbagai permasalahan yang selalu timbul terutama di bidang pendidikan. Dari 30

\footnotetext{
${ }^{20}$ Mulyasa, "Manajemen Pendidikan Karakter, Cet."

${ }^{21}$ Mulyasa.

22 Mulyasa.

${ }^{23}$ Enco Mulyasa, “Manajemen Pendidikan Karakter," Jakarta: Bumi Aksara, 2011, 165-89.

${ }^{24}$ Mulyasa, "Manajemen Pendidikan Karakter, Cet."

${ }^{25}$ Mulyasa.
} 
judul buku yang dipublikasi, penulis hanya memberikan beberapa contoh karya karya buku yang telah menjadi best seller di antaranya adalah sebagai berikut :

a. Menejemen Berbasis Sekolah (MBS)

Buku ini berisikan konsep-konsep yang ditawarkan setelah adanya otonomi sekolah, juga sebagai alternatif paradigma baru dalam manajemen pendidikan.

b. Kurikulum Berbasisi Kompetensi (KBK)

Buku di atas mengupas berbagai masalah-masalah kurikulum, juga bertujuan untuk mereformasi dalam dunia pendidikan. Buku ini menyempurnakan dari KBK yang diuji sejak 2001, meskipun mengalami perubahan - perubahan.

c. Menjadi Guru Profesional (2003)

Di dalam buku ini dijelaskan tentang keterampilan, kemampuan, sikap guru dapat dan mendidik yang benar - benar profesional.

d. Implemetasi Kurikulum 2004 (2004)

Buku ini sebagai panduan para pendidik dan sebagai pemahaman serta mengimplementasi kurikulum 2004 secara tepat waktu dan tepat sasaran.

e. Kurikulum Yang Disempurnakan

Isi dalam buku ini diantaranya berisikan tentang pentingnya kurikulum, serta sebagai respons dari kurikulum, serta sebagai respons dari kekisruhan perubahan kurikulum dan untuk jembatan bagi kepentingan guru dalam mengembangkan standar kompetensi dasar pada setiap tingkat satuan pendidikan.

f. Menjadi Kepala Sekolah Profesional, Manajemen Pendididikan Karakter, Pedoman Manajemen Berbasis Masalah, dan sebagainya.

Demikian yang dapat disajikan dari sekian banyak karya-karya ilmiah beliau. Dan masih banyak karya-karyanya yang selalu menjadikan rujukan atau referensi utama bagi para kalangan pendidik.

\section{Pemikiran Prof. Dr. H. E. Mulyasa, M.Pd tentang Model Pembelajaran Berkarakter}

Pemikiran Dr. H. E. Mulyasa, M.Pd mengatakan bahwa Pembelajaran pada hakikatnya adalah proses interaksi antara peserta didik dengan lingkungan, sehingga terjadi perubahan perilaku ke arah yang lebih baik. Dalam interaksi tersebut banyak faktor yang mempengaruhinya baik faktor internal yang datang dari diri individu maupun faktor eksternal yang datang dari lingkungan luar ${ }^{26}$.

Adapun model pembelajaran berkarakter menurut Prof. Dr. H. E. Mulyasa M.Pd diantaranya : Pembiasaan dan keteladanan, pembinaan disiplin peserta didik, CTL (Contectual teaching and learning), bermain peran (role playing), dan pembelajaran partisipatif (participative instruction).

\footnotetext{
${ }^{26}$ Enco Mulyasa, Kurikulum Berbasis Kompetensi: Konsep, Karakteristik, Dan Implementasi (PT Remaja Rosdakarya, 2002).
} 
1. Pembiasaan

Pembiasaan merupkan sesuatu yang sengaja dilakukan secara berulang-ulang agar sesuatu itu dapat menjadi kebiasaan. Pembiasaan sebenarnya berintikan pengalaman, yang dibiasakan itu adalah sesuatu yang diamalkan. Pembiasaan dalam pendidikan hendaknya dilakukan sedini mungkin.

Pendidikan melalui pembiasaan dapat dilaksanakan secara terprogram dalam pembelajaran, dan secara tidak terprogram dalam kegiatan sehari-hari.

a. Kegiatan pembiasaan terprogram dalam pembelajaran dapat dilaksanakan dengan perencanaan khusus dalam kurun waktu tertentu untuk mengembangkan pribadi peserta didik secara individual, kelompok, dana tau klasikal sebagai berikut:

1) Biasakan peserta didik untuk bekerja sendiri, menemukan sendiri, dan mengkontruksi sendiri pengetahuan, keterampilan, dan sikap baru dalam setiap pembelajaran.

2) Biasakan melakukan kegiatan inkuiri dalam setiap pembelajaran.

3) Biasakan belajar secara kelompok untuk menciptakan "masyarakat belajar".

4) Biasakan untuk belajar dari berbagai sumber.

5) Guru harus membiasakan diri menjadi model dalam setiap pembelajaran.

b. Kegiatan secara tidak teprogram dapat dilaksanakan sebagai berikut :

1) Rutin, yaitu pembiasaan yang dilakukan terjadwal, seperti upacara bendera, senam, shalat berjamaah, keberaturan, pemeliharan kebersihan dan kesehatan diri.

2) Spontan, adalah pembiasaan yang tidak terjadwal dalam kejadian khusus seperti: pembentukkan prilaku memberi salam, penugasan memberi salam, membuang sampah sesuai tempatnya, antre, mengatasi silang pendapat (pertengkaran).

3) Keteladanan, adalah pembiasaan dalam bentuk prilaku seharihari seperti: berpakaian rapi, berbahasa yang baik, rajin membaca, memuji kebaikan dan keberhasilan orang lain, dating tepat waktu ${ }^{27}$.

Dengan demikian metode pembiasaan ini adalah sebagai bentuk pendidikan bagi manusia yang prosesnya dilakukan secara bertahap, dan menjadikan pembiasaan itu sebagai teknik pendidikan yang dilakukan dengan membiasakan sifat-sifat baik sebagai rutinitas, sehingga jiwa dapat menunaikan kebiasaan itu tanpa terlalu payah, tanpa kehilangan banyak tenaga, dan tanpa menemukan banyak kesulitan.

${ }^{27}$ Mulyasa, "Manajemen Pendidikan Karakter, Cet." 
2. Keteladanan

Perilaku guru memiliki andil yang sangat besar terhadap keberhasilan pendidikan, pribadi guru akan menjadi teladan dan sangat besar pengaruhnya pertumbuhan dan perkembangan pribadi para peserta didik. Oleh karena itu setiap guru dituntut untuk memiliki kompetensi kepribadian yang memadai, bahkan kompetensi ini akan melandasi atau menjadi landasan bagi kompetensi-kompetensi lainnya. ${ }^{28}$

Dalam keteladan ini , guru harus tampil beda, harus berbeda dari penampilan-penampilan orang lain yang bukan guru, beda dan unggul (diferent and distingtif). Sebab penampilan guru, bisa membuat peserta didik senang belajar, bisa membuat peserta didik betah di kelas, tetapi bisa juga membuat peserta didik malas belajar bahkan malas masuk kelas seandainya penampilan gurunya acak-acakan tidak karuan. Disinilah guru harus menjadi teladan agar bisa ditiru dan diteladani oleh peserta didiknya.

Konsep keteladanan ini sudah diberikan dengan cara Allah mengutus nabi Muhammad Saw untuk menjadi panutan yang baik bagi umat Islam sepanjang sejarah dan bagi semua manusia di setiap masa dan tempat. Baliau bagaikan lampu terang dan bulan petunjuk jalan. Keteladanan ini harus senantiasa dipupuk, dipelihara, dan dijaga oleh para pengemban risalah. Guru harus memiliki sifat tertentu sebab guru ibarat naskah asli yang hendak difotokopi. Ahmad syauki berkata, "Jika guru berbuat salah sedikit saja, akan lahirlah murid-murid yang lebih buruk baginya”. Allah berfirman dalam QS. Al-Ahdzab 45-46, yang berbunyi :

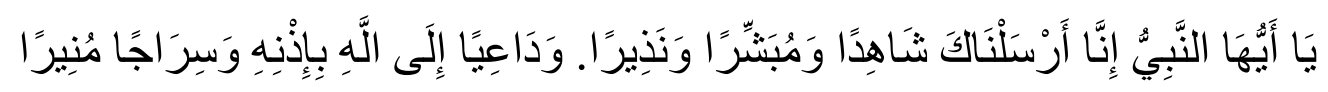

Artinya : "Hai Nabi sesungguhnya kami mengutusmu untuk jadi saksi, dan pembawa kabar gembira dan pemberi peringatan, dan untuk jadi penyeru kepada Agama Allah dengan izin-Nya dan untuk jadi cahaya yang menerangi. (QS:AlAhzab ayat: $45-46)^{29}$

Dari ayat tersebut dapat kita pahami secara teoritis menjadi teladan merupakan bagian intrgrasi dari seseorang guru, sehingga menjadi guru berarti menerima tanggung jawab untuk menjadi teladan. Guru yang baik adalah guru yang menyadari kesenjangan antara apa yang diinginkan dengan apa yang dimilikinya, kemudian menyadari kesalahan ketika memang bersalah. Kesalahan perlu diikuti dengan sikap merasa dan berusaha untuk tidak mengulanginya. Dengan kata lain guru yang baik adalah guru yang sadar diri,menyadarin kelebihan dan kekurangan (self consciousness)

3. Pembinaan Disiplin Peserta Didik

Disiplin adalah suatu keadaan tertib di mana orang-orang yang tergabung dalam suatu organisasi tunduk pada peraturan-peraturan yang telah ada dengan rasa senang hati.

\footnotetext{
${ }^{28}$ Mulyasa.

${ }^{29}$ Departemen Agama RI, Al-Qur'an dan Terjemah Special For Woman, (Bandung; Sygma exagrafika, 2009), 424
} 
Dalam rangka menyukseskan pendidikan karakter, guru harus mampu menumbuhkan disiplin peserta didik, terutama disiplin diri (self discipline). Guru harus mampu membantu peserta didik mengembangkan pola perilakunya, meningkatkan standar prilakunya, dan melaksanakam aturan sebagai alat untuk menegakkan disiplin. Untuk mendisiplinkan peserta didik perlu dimulai dengan prinsip yang sesuai dengan tujuan pendidikan nasional, yakni sikap demokratis, sehingga peraturan disiplin perlu berpedoman pada hal tersebut, yakni dari, oleh dan untuk peserta didik, sedangkan guru tut wuri handayani. ${ }^{30}$

Disiplin sangat penting artinya bagi peserta didik, karena itu ia harus ditanamkan secara terus-menerus kepada mereka. Dengan penanaman yang terus menerus, maka disiplin tersebut akan menjadi kebiasaan bagi peserta didik. Membina disiplin peserta didik harus mempertimbangkan berbagai situasi, dan memahami faktor-faktor yang mempengaruhinya. Oleh karena itu disarankan kepada guru untuk melakukan hal-hal sebagai berikut :

a. Memulai seluruh kegiatan dengan disiplin waktu, dan patuh/taat aturan.

b. Mempelajari pengalaman peserta didik di sekolah melalui kartu catatan kumulatif

c. Mempelajari nama-nama peserta didik secara langsung, misalnya melalui daftar hadir di kelas

d. Mempertimbangkan lingkungan pembelajaran dan lingkungan peserta didik

e. Memberikan tugas yang jelas, dapat dipahami, sederhana dan tidak bertele-tele

f. Menyiapkan kegiatan sehari-hari agar apa yang dilakukan dalam pembelajaran sesuai dengan yang direncanakan, yidak terjadi banyak penyimpangan.

g. Berbuat sesuatu yang berbeda dan bervariasi, jangan monoton, sehingga membantu disiplin dan gairah belajar peserta didik.

h. Membuat peraturan yang jelas dan tegas agar bisa dilaksanakan dengan sebaik-baiknya oleh peserta didik dan lingkungannya.

Melalui berbagai upaya tersebut diharapkan tercipta iklim yang kondusif bagi implementasi pendidikan karakter, sehingga peserta didik dapat menguasai berbagai kompetensi sesuai dengan tujuan. Diantara pembiasaan yang bisa dilakukan di sekolah adalah disiplin dan mematuhi peraturan sekolah, terbiasa senyum ramah pada orang, dan kebiasaan-kebiasaan lain yang menjadi aktivitas sehari-hari. Untuk bisa melakukannya memang menuntut orang tua dan guru bisa menjadi teladan pertama dan utama bagi anak. Jadi jika ingin membiasakan siswa untuk taat aturan maka guru lah yang pertama harus lebih dulu taat aturan.

${ }^{30}$ E. Mulyasa, Manajemen Pendidikan Karakter, (Jakarta; Bumi Aksara, 2013), 172 
4. CTL (Contextual Teaching and Learning)

Pembelajaran kontekstual (Contextual Teaching and Learning) yang sering disingkat CTL merupakan salah satu model pembelajaran yang dapat digunakan untuk mengefektifkan dan menyukseskan pendidikar karakter di sekolah. Dengan kata lain, CTL dapat dikembangkan menjadi salah satu model pembelajaran berkarakter, karena dalam pelaksanaanma lebih menekankan pada keterkaitan antara materi pembelajaran dengan dunia kehidupan peserta didik secara nyata, sehingga para peserta didik mampu menghubungkan dan menerapkan kompetensi hasil belajar dalan kehidupan sehari-hari.

Melalui proses penerapan karakter dalam kehidupan sehari-hari peserta didik akan merasakan pentingnya belajar, dan mereka akan memperoleh makna yang mendalam terhadap apa yang dipelajarinya. CTL memungkinkan proses belajar yang tenang dan menyenangkan, karena pembelajaran dilakukan secara alamiah, sehingga peserta didik dapat mempraktikkan karakter-karakter yang dipelajarinya dan yang telah dimilikinya secara langsung. Pembelajaran kontekstual mendorong peserta didik memahami hakikat, makna, dan manfaat belajar, sehingga memungkinkan mereka rajin, dan termotivasi untuk senantiasa belajar, bahkan kecanduan belajar. Kondisi tersebut terwujud, ketika peserta didik menyadari tentang apa yang mereka perlukan untuk hidup, dan bagaimana cara menggapainya. Dalam pembelajaran kontekstual tugas, guru adalah memberikan kemudahan belajar kepada peserta didik, dengan menyediakan berbagai sarana dan sumber belajar yang memadai serta menciptakan iklim yang kondusid bagi tumbuh kembangnya setiap karakter peserta didik.

5. Bermain Peran

Metode bermain peran adalah salah satu proses belajar mengajar yang tergolong dalam metode simulasi. Metode simulasi adalah suatu cara pengajaran dengan melakaukan proses tingkah laku secara tiruan. Dengan demikian pembelajaran bermain peran merupakan salah satu strategi pembelajaran yang diarahkan pada upaya pemecahan masalah-masalah yang berkaitan dengan hubungan antara manusia (interpersonal relationship), terutama yang menyangkut kehidupan sekolah, keluarga maupun perilaku masyarakat sekitar peserta didik.

Bermain peran disebut juga bermain simbolik, pura-pura fantasi, imajinasi, atau bermain drama. Bermain peran ini sangat penting untuk perkembangan kognisi, social, dan emosi anak pada usia tiga sampai enam tahun. Bermain peran dipandang sebagai sebuah kekuatan yang menjadi dasar perkembangan daya cipta, tahapan inagatan, kerja sama kelompok, penyerapan kosa kata, konsep hubungan kekeluargaan, pengendalian diri, keterampilan spasial, afeksi, dan keterampilan kognisi.

Hampir dalam setiap pembelajaran, guru dan peserta didik sering dihadapkan pada berbagai masalah, baik yang berkaitan dengan mata pelajaran maupun yang menyangkur hubungan sosial. Pemecahan masalah pembelajaran dapat dilakukan melalui berbagai cara, melalui diskusi kelas, tanya jawab antara guru dan peserta didik, penemuan dan inkuiri. 
Melalui bermain peran, para peserta didik mencoba mengeksplorasi hubungan-hubungan antar manusia dengan cara memperagakannya dan mendiskusikannya sehingga secara bersama-sama para peserta didik dapat mengeksplorasi perasaan-perasaan, sikap-sikap, nilai-nilai, dan berbagai strategi pemecahan masalah. ${ }^{31}$

6. Pembelajaran Partisipatif

Pembelajaran partisipatif sering juga diartikan sebagai keterlibatan peserta didik dalam perencanaan, pelaksanaan, dan evaluasi pembelajaran. Indikator pembelajaran partisipatif sebagaimana dikemukakan knowles adalah sebagai berikut

a. Adanya keterlibatan emosional dan mental peserta didik

b. Adanya kesediaan peserta didik untuk memberikan kontribusi dalam mencapai tujuan,

c. Dalam kegiatan belajar terdapat hal yang menguntungkan peserta didik. Pembelajaran partisifatif dapat dikembangkan dengan prosedur sebagai berikut:

1) Menciptakan pengalaman yang mendorong peserta didik siap belajar.

2) Membantu peserta didik menyusun kelompok, agar dapat saling belajar dan membelajarkan.

3) Membantu peserta didik untuk mendiagnosis dan menemukan kebutuhan belajarnya

4) Membantu peserta didik menyusun karakter, kompetensi, dan tujuan belajar.

5) Membantu pesrta didik merancang pola karakter yang sesuai dengan pengalaman belajar.

6) Membantu peserta didik melakukan kegiatan belajar berkarakter.

7) Membantu peserta didik melakukan evaluasi diri terhadap proses dan hasil belajar pendidikan karakter

Pendidikan karakter melalui pembelajara partisipatif menuntut guru berperan sebagai fasilitator dengan memberikan kemudahan belajar kepada peserta didik melalui langkah-langkah di atas, sehingga membantu peserta didik dalam menemukan dirinya, membuat kompetensi dan karakter pribadinya.

Menurut E. Mulyasa model-model pembelajaran terebut diharapkan dapat mewujudkan suasana belajar dan proses pembelajaran sehingga peserta didik secara aktif mengembangkan potensi dirinya untuk memiliki kekuatan spiritual keagamaan, pengendalian diri, kepribadian, kecerdasan, akhlak mulia, serta keterampilan yang diperlukan dirinya, masyarakat, bangsa, dan negara.

${ }^{31}$ E. Mulyasa, Manajemen Pendidikan Karakter, (Jakarta; Bumi Aksara, 2013), 179 


\section{Hasil Analisis Model Pembelajaran Berkarakter Menurut E. Mulyasa dan Relevansinya Terhadap Pendidikan Islam}

1. Dapat mendorong atau mempercepat prilaku

Menurut peneliti pembiasaan atau kebiasaan bisa diklasifikasikan menjadi dua bagian, pertama kebiasaan baik, kedua kebiasaan buruk. Kebiasaan dapat mendorong dan mempercepat prilaku seseorang bisa kearah baik ataupun kearah buruk, tergantung dari pendidik tersebut. Oleh karena itu dengan pembiasaan yang positif yang dilakukan oleh pendidik dalam pembelajaran, dapat membentuk karakter peserta didik menjadi baik, dan sebaliknya jika seorang guru membiasakan prilaku negatif maka peserta didik memiliki karakter buruk, peserta didik akan memperhatikan dan meniru apa yang dibiasakan oleh guru tersebut.

Pada hakikatnya seorang anak dilahirkan dalam keadaan suci dan bersih, dalam keadaan seperti ini anak mudah menerima kebaikan atau keburukan, Hal ini dijelaskan dalam firman Allah SWT:

Artinya: “Dan demi jiwa serta penyempurnaannya (ciptaanya), Maka Allah mengilhamkan kepada jiwa itu (jalan) kefasikan dan ketakwaannya, Sesungguhnya beruntunglah orang yang mensucikan jiwa itu, Dan sesungguhnya merugilah orang yang mengotorinya" (QS. As-Syamsy[91]:(7-10)

Ayat tersebut sangat mengidentifikasikan bahwa manusia mempunyai kesempatan sama untuk membentuk karakternya, apakah dengan pembiasaan yang baik atau dengan pembiasaan yang buruk.

Dalam Islam, mengajarkan dan mempergunakan kebiasaan itu sebagai salah satu teknik pendidikan, lalu mengubah seluruh sifat-sifat baik menjadi kebiasaan, sehingga jiwa dapat menunaikan kebiasaan, tanpa perlu payah, tanpa kehilangan banyak tenaga dan tanpa menemukan banyak kesulitan. Al-Qur'an juga memberikan model pembiasaan dan praktik keilmuan. Al-Qur'an sangat banyak memberikan dorongan agar manusia selalu melakukan kebaikan. Ayatayat Al-Qur'an yang menekankan pentingnya pembiasaan bisa terlihat bada term "amilus shalihat" (mereka selalu melakukan amal kebaikan atau membiasakan beramal sholeh) yang diungkap sebanyak 73 dalam Al-Qur'an hal ini memperlihatkan bahwa pentingnya pembiasaan suatu amal kebaikan dalam proses pembinaan dan pendidikan karakter dalam Islam ${ }^{32}$.

Model Pembiasaan hendaknya dimulai sedini mungkin. Bukan hanya ketika proses pembelajaran saja, karena Rasulullah SAW telah memerintahkan kepada orang tua, dalam hal ini pendidik agar mereka menyuruh anak-anak mengerjakan sholat, ketika mereka berumur tujuh tahun, ini termasuk kedalam pembiasaan baik. Dan dalam pembelajaran dapat dilakukan oleh pendidik dengan cara membiasakan anak mengucap salam, berdo'a sebelum belajar, membuang sampah pada tempatnya dan sebagainya. Dalam hadits-hadits Nabi Muhammad SAW juga terdapat model pembiasaan dalam melakukan pendidikan akhlak harian. Sebagai contoh hadis yang diriwayatkan oleh Abu

\footnotetext{
32 Ibnu Rusydi, "Paradigma Pendidikan Agama Integratif-Transformatif," Jurnal Pendidikan Islam, 1970, https://doi.org/10.14421/jpi.2011.11.105-120.
} 
Hurairah, Rasulullah SAW bersabda, "Makanlah dengan Bismillah, dan gunakanlah tangan kanan, dan makanlah apa yang dekat kepadamu”. Maka sejak itu begitulah kebiasaan akhlakku makan." (HR Abu dawud, Tirmizi, Ibnu Majah dan Baihaqi).

Dengan demikian proses pendidikan yang terkait dengan prilaku ataupun sikap tanpa diikuti dan didukung adanya praktik dan pembiasaan pada diri, maka pendidikan itu hanya jadi angan-angan belaka karena pembiasaan dalam proses pendidikan sangat dibutuhkan. Hal ini menunjukkan bahwa metode pembiasaan dalam membentuk karakter sangat terbuka luas, dan merupakan metode yang tepat dalam proses pembelajaran sehingga terbentuknya karakter yang baik.

2. Menjadikan peserta didik berakhlakul kharimah

Dengan menggunakan model keteladanan dalam Islam disebut dengan model Qudwah merupakan salah satu aspek terpenting dalam mewujudkan integrasi iman, ilmu, dan akhlak. Dengan adanya figure utama yang menunjang hal tersebut dialah sang pendidik, perilaku guru memiliki pengaruh yang sangat besar terhadap keberhasilan pendidikan, dan pendidik menjadi cermin bagi peserta didiknya.

Dalam Al-Qur'an kalimat qudwah diungkap dengan istilah "uswah" istilah ini terdapat tiga kali dalam Al-Qur'an yaitu Qs. Al-Ahzab:21 dan Qs. Mumtahanah: 4,6 dan Qs. An-Nisaa: 48.

Allah SWT menunjukkan bahwa contoh keteladanan dari kehidupan Nabi Muhammad SAW adalah mengandung nilai paedagogis bagi manusia (para pengikutnya).

Allah SWT berfirman dalam QS. Al-Ahdzab ayat 21:

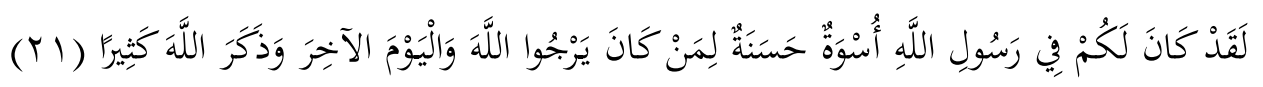

Artinya : "Sesungguhnya telah ada pada iri Rasulullah itu suri teladan yang baik bagimu (yaitu) bagi orang yang mengharap (rahmat Allah dan (kedatangan) hari kiamat dan ia banyak menyebut Allah". (Qs. Al Ahdzab:21)

Dari ayat diatas sudah jelas bahwa Allah SWT telah menegaskan dan mengajarkan kepada hambanya untuk selalu meneladani serta mengikuti sifat dan sikap keteladanan Rasulullah SAW dengan baik. Sebagai seorang pendidik Rasulullah memiliki karakteristik yang ada dalam dirinya. Pertama, pembawaannya yang tenang dan penuh kasih sayang sehingga menjadi motivator, tawadhu' tidak menyulitkan siapapun yang berinteraksi meskipun dengan para musuh-musuhnya. Kedua, memiliki kesempurnaan akhlak, ketiga, memiliki kemampuan dalam memilih kata-katayang ingin dikeluarkan, keempat, memliki keagungan dalam hal keilmuan perbuatan.

Menurut peneliti model keteladanan ini memiliki tiga karakteristik, pertama: mudah, peserta didik lebih cepat melihat kemudian melakukan daripada hanya

${ }^{3}$ Departemen Agama RI, Al-Qur'an dan Terjemah Special For Woman, (Bandung; Sygma exagrafika, 2009), 42 
dengan verbal. Kedua, minim kesalahan karena langsung mencontohkan. Ketiga, lebih dalam pengaruhnya, berkesan dan membekas dalam hati manusia disbanding teori.

Contoh dari keteladanan yang diberikan guru dalam proses pembelajaran ataupun orang tua dalam mendidik anaknya diantaranya: Mengajarkan hal-hal yang baik. berbicara baik dan santun, jujur, bijaksana dalam bertindak, berpakaian sopan, amanah, dapat dipercaya, dan sebagainya. Sebab peserta didik akan meniru perilaku yang dicontohkan oleh pendidik karena seorang anak memang sangat membutuhkan panutan atau contoh dalam keluarga.

Jika orang tua atau pendidik melakukan perilaku buruk maka seorang anak yang melihat orang tua berbuat dusta, tidak mungkin ia belajar jujur. Seorang anak yang melihat orang tuanya berkata kasar tidak mungkin akan bertutur manis, seorang anak yang melihat orang tuanya bersikap kasar, tidak mungkin ia akan belajar kasih sayang. Oleh karena itu model keteladanan ini sangat penting dalam pendidikan baik di sekolah maupun di lingkungan keluarga. Sebagai pendidik hendaknya mencontohkan prilaku baik atau teladan yang baik sehingga menjadikan peserta didik yang berakhlakul kharimah.

3. Melatih kedisiplinan peserta didik.

Disiplin sangat penting bagi peserta didik, karena itu ia harus ditanamkan secara terus-menerus kepada mereka. Dengan penanaman yang terus menerus, maka disiplin tersebut akan menjadi kebiasaan bagi peserta didik. Jika peserta didik ditanamkan sikap disiplin maka ia akan menjadi pribadi yang sigap dan baik dalam memanfaatkan waktu. Dalam pendidikan Islam, mengajarkan ummat untuk disiplin, Allah berfirman dalam QS. Al-Ashr yang atinya :

"Demi masa. Sesungguhnya manusia itu benar-benar dalam kerugian, kecuali orang-orang yang beriman dan mengerjakan amal saleh dan nasehat menasehati supaya mentaati kebenaran dan nasehat menasehati supaya menetapi kesabaran." [Al-'Ashr/ 103: 1- 3]

Dalam Surat ini, Allâh Subhanahu wa Ta'ala telah bersumpah dengan masa, yang merupakan ajang dan medan perlombaan manusia dalam beramal. Masa atau waktu, di mana sangat beragam manusia dalam menggunakannya. Ada yang menggunakan waktunya dalam ketaatan kepada Allâh Subhanahu wa Ta'ala dan memperbaiki umat. Mereka inilah kaum yang beruntung. Dan ada juga yang waktunya berlalu begitu saja dengan sia-sia, kelompok ini menghabiskan waktunya dalam kemaksiatan dan merusak umat.

Dalam hal pendidikan, untuk meningkatkan kedisiplinan siswa hendaknya dengan cara sebagai berikut : Membuat peraturan yang jelas dan konsisten, menggunakan waktunya sebaik mungkin, misalnya tepat waktu dalam KBM, tidak pernah telat datang ke sekolah dan sebagainya sehingga peserta didik akan terbiasa dan terlatih menjadi disiplin dan taat pada peraturan sekolah.

4. Menciptakan suasana senang

Islam menganjurkan untuk menciptakan suasana senang sebagai upaya pendidikan. Ajaran Islam memberikan prioritas pada upaya memotivasi suasana gembira dibanding dengan ancaman dan hukuman. Partisipasi guru di dalam situasi belajar mengajar. Hal ini dimaksudkan untuk menunjukkan tanggung 
jawabnya sebagai guru. Posisi siswa yang aktif harus diawasi sekaligus diarahkan sejalan dengan nilai-nilai Islami. Firman Allah SWT mengisyaratkan hal ini: QS An-Nisa ayat 9:

Artinya: "Dan hendaklah takut kepada Allah orang-orang yang sekiranya mereka meninggalkan keturunan yang lemah dibelakang mereka, yang mereka khawatir terhadap (kesejahteraan). Oleh sebab itu hendaklah mereka bertakwa kepada Allah dan hendaklah mereka berbicara dengan tutur kata yang benar".

Dengan adanya model pembelajaran dengan CTL memungkinkan proses belajar yang tenang dan menyenangkan, karena pembelajaran dilakukan secara alamiah, sehingga peserta didik dapat mempraktikkan karakter-karakter yang dipelajarinya dan yang telah dimilikinya secara langsung. Pembelajaran kontekstual mendorong peserta didik memahami hakikat, makna, dan manfaat belajar, sehingga memungkinkan mereka rajin, dan termotivasi untuk senantiasa belajar, bahkan kecanduan belajar.

5. Mengembangkan pemikiran peserta didik dengan cara bekerja sendiri, dan mengkontruksi sendiri pengetahuan dan keterampilannya

Model pembelajaran dengan Bermain peran dalam pembelajaran merupakan salah satu strategi pembelajaran yang diarahkan pada upaya pemecahan masalah-masalah yang berkaitan dengan hubungan antara manusia (interpersonal relationship), terutama yang menyangkut kehidupan sekolah, keluarga maupun perilaku masyarakat sekitar peserta didik. Melalui bermain peran, para peserta didik mencoba mengeksplorasi hubungan-hubungan antar manusia dengan cara memperagakannya dan mendiskusikannya sehingga secara bersama-sama para peserta didik dapat mengeksplorasi perasaan-perasaan, sikap-sikap, nilai-nilai, dan berbagai strategi pemecahan masalah ${ }^{34}$.

Dalam metode pendidikan Islam ada metode membuat perumpamaan dan bercerita untuk mengambil pelajaran. Dalam Al-Qur'an teknik ini sering sekali digunakan. Betapa banyak contoh yang dibuat Allah SWT untuk menerapkan kebenaran dalam berbagai aspeknya kepada manusia. Contoh-contoh itu bersifat praktis sehingga mudah dipahami. Ketika mereka mendengarkan cerita peserta didik bisa merasakan apa yang dirasakan orang lain, mereka akan belajar dari pengalaman tersebut dan bagaimana mengatasi permasalahan tersebut.

6. Menjadikan peserta didik aktif dan kreatif

Dengan model pembelajaran partisipatif guru dapat melibatkan peserta didik dalam perencanaan, pelaksanaan, dan evaluasi pembelajaran. Pembelajara partisipatif menuntut guru berperan sebagai fasilitator dengan memberikan kemudahan belajar, serta memberikan bimbingan dan motivasi kepada peserta didik. Sehingga menjadikan anak menjadi lebih aktif dan kreatif.

Bimbingan dan latihan dilakukan secara bertahap dengan melihat kemampuan yang dimiliki anak untuk kemudian ditingkatkan perlahan-lahan.

\footnotetext{
${ }^{34}$ Ali Miftakhu Rosyad and Darmiyati Zuchdi, "Aktualisasi Pendidikan Karakter Berbasis Kultur Sekolah Dalam Pembelajaran IPS Di SMP," Harmoni Sosial: Jurnal Pendidikan IPS, 2018,

https://doi.org/10.21831/hsjpi.v5i1.14925.
} 
Bimbingan dapat berupa lisan, latihan, dan keterampilan. Bimbingan akan tepat apabila disesuaikan dengan kemampuan, kebutuhan dan minat.

Sebagaimana Allah SWT telah membimbing kita sebagai manusia, Allah SWT berfirman dalam QS. Ar-rum:30

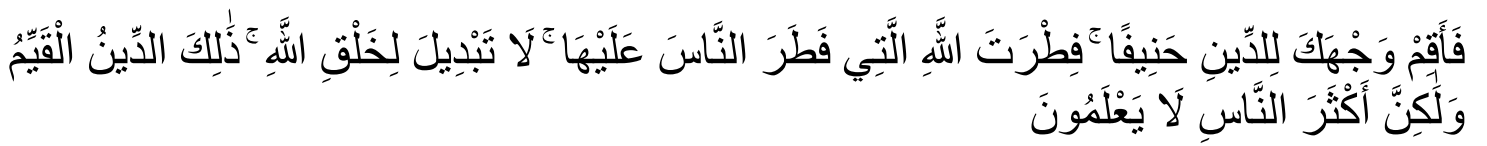

Artinya: "Maka hadapkanlah wajahmu dengan lurus kepada agama Allah; (tetaplah atas) fitrah Allah yang telah menciptakan manusia menurut fitrah itu. Tidak ada peubahan pada fitrah Allah. (Itulah) agama yang lurus; tetapi kebanyakan manusia tidak mengetahui”.(QS. Ar-rum:30)

Berdasarkan analisa dari buku manajemen pendidikan karakter menurut Prof. Dr. H. E. Mulyasa mengenai model pembelajaran berkarakter dan relevansinya tehadap pendidikan Islam, peneliti mengungkapkan bahwa modelmodel yang diungkapkan oleh Prof. Dr. H. E Mulyasa ini sebelumnya sudah diterapkan oleh Pendidikan Islam itu sendiri, hanya saja yang membedakannya dari pelafalan nama model ada yang sama dan ada yang berbeda tapi tujuannya sama.

Ada hal yang menarik yang tidak diungkapkan oleh buku pendidikan karakter yang menurut peneliti ini sangat penting juga dalam pembentukkan karakter, dalam pendidikan Islam, yaitu : Metode penghargaan dan hukuman, metode ini dianggap dapat membantu dalam menanamkan karakter pada anak. Metode dengan penghargaan (hadiah) dan hukuman penting untuk dilakuakan karena pada dasarnya setiap orang dipastikan membutuhkan penghargaan dan ingin dihargai. Anak adalah fase dari perkembangan manusia yang sangat membutuhkan penghargaan. Tapi penghargaan itu tidak boleh berelebihan. Dengan adanya penghargaan, anak akan lebih termotivasi untuk melakukan perbuatan-perbuatan baik, selanjutnya dengan penghargaan biasanya anak merasa bangga dan lebih percaya diri. Kepercayaan diri inilah yang biasanya membuat anak kreatif dalam berpikir dan bertindak.

Selain penghargaan, metode hukuman juga biasa diterapkan dalam pembentukkan karakter anak. Metode hukuman ini boleh diterapkan jika seluruh metode-metode tidak berhasil. Jika hukuman terpaksa harus diberikan, maka berhati-hatilah jangan memberikan hukuman secara berlebihan, jangan menghukum ketika marah, jangan memukul bagian-bagian tetentu dari anggota tubuh anak seperti wajah, dan usahakan hukuman itu bersifat positif dan adil (sesuai dengan kesalahan anak).

Penggunaan model pembelajaran berkarakter dalam pembelajaran dapat memberikan manfaat bagi pendidik maupun peserta didik daintaranya:
a. Menciptakan suasana yang mendorong peserta didik siap belajar
b. Menciptakan masyarakat belajar
c. Mengembangkan pemikiran peserta didik
d. Menyenangkan tidak membosankan 
e. Belajar terarah dan bergairah (bersemangat)

f. Pembelajaran efektif dan efisien

g. Peserta didik kritis dan guru kreatif

Dengan model pembelajaran berkarakter dalam pembelajaran dapat memudahkan Pendidikan Islam atau Pendidikan Agama Islam di Sekolah dalam mendidik dan membentuk karakter peserta didik. Dengan demikian peneliti dapat meyimpulkan dari analisa diatas bahwasannya model pembelajaran berkarakter dengan pendidikan Islam memiliki keterkaitan atau tujuan yang sama, yaitu keduanya sama-sama ingin membentuk karakter/akhlak yang berakhlakul kharimah yang mana itu merupakan tujuan sebenarnya dari pendidikan.

\section{Simpulan}

Dari pembahasan tentang model pembelajaran berkarakter dan relevansinya terhadap pendidikan Islam sebagaimana dipaparkan di atas, maka dapat diambil kesimpulan sebagai berikut:

Pertama, model pembelajaran berkarakter menurut E. Mulyasa, adalah model belajar mengajar dengan menggunakan pembiasaan dan keteladanan, pembinaan disiplin, CTL (contectual teaching and learning), bermain peran (role playing), dan pembelajaran partisipatif (Participative intruction). Dari beberapa model pembelajaran tersebut diharapkan dapat menciptakan suasana yang efektif dan efisien dan dapat membentuk karakter siswa yang baik.

Kedua, adapun relevansi pemikiran E.Mulyasa tentang model pembelajaran berkarakter dengan pendidikan Islam yaitu memiliki keterkaitan atau tujuan yang sama, yaitu keduanya sama-sama ingin membentuk karakter/akhlak yang berakhlakul kharimah yang mana itu merupakan tujuan sebenarnya dari pendidikan.

\section{DAFTAR PUSTAKA}

Assegaf, Abd. Rachman. Filsafat Pendidikan Islam: Paradigma Baru Pendidikan Hadhari Berbasis Integratif-Interkonektif. PT RajaGrafindo Persada, 2011.

Herimanto, Winarno. "Ilmu Sosial Dan Budaya Dasar." Jakarta: Bumi Aksara, 2008.

Mulyasa, Enco. Kurikulum Berbasis Kompetensi: Konsep, Karakteristik, Dan Implementasi. PT Remaja Rosdakarya, 2002.

___. "Manajemen Pendidikan Karakter." Jakarta: Bumi Aksara, 2011, 165-89.

Mulyasa, H E. "Manajemen Pendidikan Karakter, Cet.” V, Jakarta: Bumi Akara, 2013, 165.

Mulyono, M, and Ismail Suardi Wekke. "Strategi Pembelajaran Di Abad Digital." Yogyakarta: Penerbit Gawe Buku, 2018.

Pendidikan, Implementasi, Karakter Dalam, and Ali Miftakhu Rosyad. "Al-Afkar, Journal for Islamic Studies Ali Miftakhu Rosyad IMPLEMENTASI PENDIDIKAN KARAKTER DALAM PEMBELAJARAN PENDIDIKAN AGAMA ISLAM DI SEKOLAH MUHAMMADIYAH DI KABUPATEN INDRAMAYU Al-Afkar, 
Journal for Islamic Studies THE IMPLEMENTATION OF CHARACTER EDUCATION THROUGH LEARNING OF ISLAMIC STUDIES IN MUHAMMADIYAH SCHOOL IN INDRAMAYU DISTRICT” 4, no. 1 (2019). https://doi.org/10.5281/zenodo.3321357.

Rosyad, Ali Miftakhu, and Darmiyati Zuchdi. "Aktualisasi Pendidikan Karakter Berbasis Kultur Sekolah Dalam Pembelajaran IPS Di SMP.” Harmoni Sosial: Jurnal Pendidikan IPS, 2018. https://doi.org/10.21831/hsjpi.v5i1.14925.

Rusman, Dr, and M Pd. "Model-Model Pembelajaran." Raja Grafindo, Jakarta, 2012.

Rusydi, Ibnu. "Paradigma Pendidikan Agama Integratif-Transformatif." Jurnal Pendidikan Islam, 1970. https://doi.org/10.14421/jpi.2011.11.105-120.

Sugiyono. Metode Penelitian Pendidikan:(Pendekatan Kuantitatif, Kualitatif Dan $R$ E D). Alfabeta, 2008.

Sulhan, Najib. "Pendidikan Berbasis Karakter." Surabaya: PT JePe Press Media Utama, 2010.

Usman, Moh Uzer. "Menjadi Guru Profesional.” Bandung: PT. Remaja Rosdakarya, 2002. 